\title{
Digest of Important Canadian Cases Reported in 1976 in the Fields of Public International Law and Conflict of Laws
}

Sharon A. Williams

Osgoode Hall Law School of York University, sawilliams@osgoode.yorku.ca

Source Publication:

Canadian Yearbook of International Law. Volume 15 (1977), p. 373-394.

Follow this and additional works at: https://digitalcommons.osgoode.yorku.ca/scholarly_works

Part of the Conflict of Laws Commons, and the International Law Commons

(c) $($ ) $\Theta \Theta$

This work is licensed under a Creative Commons Attribution-Noncommercial-No Derivative Works 4.0 License.

\section{Recommended Citation}

Williams, Sharon A. "Digest of Important Canadian Cases Reported in 1976 in the Fields of Public International Law and Conflict of Laws." Canadian Yearbook of International Law 15 (1977): 373-394.

This Commentary is brought to you for free and open access by the Faculty Scholarship at Osgoode Digital Commons. It has been accepted for inclusion in Articles \& Book Chapters by an authorized administrator of Osgoode Digital Commons. 


\title{
Digest of Important Canadian Cases Reported in 1976 in the Fields of Public International Law and Conflict of Laws
}

\author{
Compiled by
}

SHARON A. WILLIAMS*

\section{Public International Law}

Criminal Law - Territorial Jurisdiction - Theft - Place where Offence Committed - Alberta Supreme Court - Appellate Division

R. v. Vroom (1976), $5^{8}$ D.L.R. (3d) 565 .

Criminal Law - "Hijacking" Aircraft - Criminal Code s. 76.I(d) - Saskatchewan Court of Appeal

R. v. Djemal, [1975] W.W.D. I84.

Extradition - Evidence - Admissibility of Documents - Depositions Duly Authenticated - Federal Court of Appeal

Re Wong Shue Teen and the United States of America (1975), 6I D.L.R. (3d) I8I, Io N.R. 27 I.

Section I 7 of the Extradition Act, R.S.C. 1970, c. E-2 I, which provides that a deposition is deemed "duly authenticated" (for use at an extradition hearing pursuant to s. I6 of the Act) if authenticated in the manner therein provided or "in the manner provided, for the time being by law" is not satisfied merely by compliance with s. 23 of the Canada Evidence Act, R.S.C. 1970, c. E-10, which provides that evidence of any record of, inter alia, a court of the United

* Sharon A. Williams, Assistant Professor of Law, Osgoode Hall Law School, York University, Toronto. 
States may be given by a certified copy thereof under the seal of such court. Section 23 merely provides for proof of the particular document and does not relate to its authenticity. Accordingly depositions taken by American authorities in Hong Kong for use in Canada on an extradition hearing do not become admissible by virtue of $\mathrm{s}$. 23 though first filed with a United States court as part of the record of and certified by that court. Certification by the American court merely establishes that the documents were filed with the court but does not establish that the documents are really statements made under oath in Hong Kong.

Extradition - Review of Magistrate's Actions in Taking Depositions to be Forwarded to Foreign Country in Course of Proceedings to Extradite Fugitive to Canada - Supreme Court of Canada

Re Vardy (1976), 8 N.R. 9 I.

Extradition - Ashburton-Webster Treaty 1842 as am. by Supplementary Conventions - "Other Property" Includes Goods and not Merely Money and Securities - Federal Court of Appeal

U.S.A. v. Couche (1975), 34 C.R.N.S. 340.

Extradition - Sufficiency of Evidence - Weighing of Evidence and Determination of Credibility not Function of Extradition JudgeSupreme Court of Canada

U.S.A. v. Sheppard (1976), 9 N.R. 215.

Extradition - Requirements to Satisfy before Issuing Warrant for Committal - British Columbia Supreme Court

Re Bing Hin Low and Li Chi Yung, [1976] 2 W.W.R. 56o.

A warrant of committal for extradition cannot be made unless the alleged offence is a crime in both the country requesting the return of an accused and in Canada. The evidence in support of the alleged crime in the demandant country is not to be weighed by the extradition judge but he may be able to exclude evidence which is manifestly unreliable or so doubtful or tainted as to make it dangerous and unjust to receive. 
Fugitive Offenders - Application for Committal of Fugitive from United Kingdom - Standard of Proof that Fugitive Committed Offence - British Columbia Provincial Court

Re Henry (1975), 23 C.C.C. (2d) $3^{8 .}$

Jurisdiction - Accused outside Canada Served with Summons Ex Parte Hearing - British Columbia Court of Appeal

Re Shulman and the Queen (1975), $5^{8}$ D.L.R. (3d) $5^{86 .}$

In penal proceedings a summons cannot be served on a person outside Canada unless such service is authorized by statute and in the absence of proper service a court has no jurisdiction over the person. There being no procedure for service of the summons outside Canada either in the Income Tax Act R.S.C. I952, c. 148 as am. or in the applicable provisions of the Criminal Code relating to summary conviction offences, the court had no jurisdiction over the accused, and, accordingly, could not proceed to hear the case.

Sovereign Immunity - Distinction between Acts Jure Imperii and Jure Gestionis - Ontario High Court

Smith v. Canadian Javelin Ltd. (1976), I2 O.R. (2d) 244, 68 D.L.R. (3d) 428.

An agency of a foreign government cannot, subject to certain exceptions such as commercial transactions and disputes concerning property in Ontario, be impleaded in the courts of that province. Thus, no action could be brought against the Securities and Exchange Commission of the United States of America in respect of the performance of its functions pursuant to United States legislation.

Transport aérien - Retard dans la livraison-Responsabilité du transporteur - Limites de responsabilité - Convention de Varsovie - Protocole de La Haye - Cour supérieure du Québec

Télé-Montage et autre c. Air Canada, [1976] C.S. 228.

Transport aérien - Dommages aux bagages d'un passager d'avion - Convention de Varsovie - Protocole de La Haye - Responsabilité - Cour provinciale du Québec

Maria Scheel - Quedrue c. Eastern Airlines et Air Canada, [1975] C.P. 228. 


\section{Confict of Laws}

\section{A. Jurisdiction}

Compétence - Action en séparation de corps - Domicile - Code procédure civile, art. 7o, Code civil, arts 6, 63, 79, 80, 81, 130Cour supérieure du Québec

Baird c. Belcourt, [1975] C.S. 499.

Compétence - Action purement personnelle - Cause d'actionNaissance aux Etats-Unis - Preuve de la doi étrangère-Code procédure civile, art. 68 - Cour supérieure du Québec

Adler c. Big "E"' Corp., [1976] C.S. 749.

Compétence - Arbitrage - Clause compromissoire - Preuve du droit étranger - Procédure - Code civil, art. 6-Cour d'appel du Québec

Sinyor Spinners of Canada Ltd. c. Leesona Corporation, [1976] C.A. 395 .

Jurisdiction - Arbitration Clause - Stay of Proceedings - Federal Court, Trial Division

Vallorbe Shipping Co. v. The Tropwave, [1975] F.C. 595 .

Notwithstanding the existence of an arbitration clause in the subcharterparty between plaintiff and C.T. Co., the charterer of the defendant ship, which provided for arbitration of disputes in New York, the plaintiff commenced an action in the Federal Court for damages and indemnification against future damages resulting from the unloading of cargo without the plaintiff's consent. The plaintiff sought a stay of proceedings on the basis of the existence of the arbitration clause. The court dismissed the motion on the ground that it would not be in the interest of justice to stay the proceedings. By bringing the action, the plaintiff expressed its intention to invoke the jurisdiction of the Federal Court, as did the defendant, by filing its defence and counterclaim. Both parties submitted to the court's jurisdiction and the claims of both parties were secured in Canada within the jurisdiction of the court.

See also Bomar Navigation Ltée v. The Hansa Bay, [1975] F.C. 
231 , where a motion for a stay of action was dismissed on the ground that the London arbitration clause in the sub-charterparty would lead to injustice.

Compétence - Contrat-Biens au Québec-Choix de la loi du contrat n'accorde pas une compétence exclusive au tribunal étranger - Art. 68, Code procédure civile - Cour supérieure du Québec

Franjan Productions Inc. et autres c. Security Investment Trust Co. S.A. et autres, [1975] C.S. I 440.

Jurisdiction-Custody-Infants Act, R.S.O. 197o, c. $222-$ Ontario Supreme Court

Vachon v. Vachon (1975), 22 R.F.L. 392.

The proper court having jurisdiction is that of the ordinary residence of the child.

Jurisdiction - Custody - Infants in Different Jurisdictions - British Columbia Supreme Court

Re Chester (1975), 62 D.L.R. (3d) 367.

Where custody of an infant is given to the maternal grandparents who reside in one province with the consent of the infant's paternal grandparents and the concurrence of the father, who resides in another jurisdiction, the court of the latter province ought not to assume jurisdiction and make a custody order with respect to the child. Such jurisdiction should only be assumed where the infant is wrongfully removed from the jurisdiction.

Jurisdiction - Custody-Manitoba Court of Appeal

Re Desilets and Desilets (1975), 6o D.L.R. (3d) 546.

Where a court in Manitoba gives custody of children to the wife with a right of access to the husband domiciled in Manitoba and where the wife subsequently removes the children to Saskatchewan and obtains an ex parte order of custody there, the courts in both Saskatchewan and Manitoba have jurisdiction over custody. The courts in Saskatchewan have jurisdiction because the children are in that province and the courts of Manitoba have jurisdiction because the domicile of the children follows the domicile of their father or 
because of the connection of the children to Manitoba, their having been born there. See also (1975), 2 I R.F.L. 297 (Man. C.A.).

Jurisdiction - Custody - Separation Agreement - Prince Edward Island Supreme Court

Furjan v. Furjan (1976), 23 R.F.L. 321.

The court held it to be unfair that the applicant in the circumstances of the case should take the child from Ontario where he was ordinarily resident and in which the respondent had lawful custody of him under a separation agreement, and then in breach of that agreement seek the aid of the Prince Edward Island Court to obtain custody on the alleged grounds that it was in the best interest of the child. The court applied Re D.J.C. and W.C. et al. (1975), 57 D.L.R. (3d) 694, 8 O.R. (2d) 3 ro (Ont. C.A.).

Compétence - Garde des enfants - Résidence en Ontario - Domicile réel à Montréal - Cour supérieure du Québec

Wojtsak c. Chaulk, [1975] C.S. 494.

Compétence - Divorce étranger - Garde des enfants - Demande de modification-Domicile des enfants à Montréal-Cour supérieure du Québec

Solomon c. Lornstein, [ 1975] C.S. 505.

Quebec courts have jurisdiction to hear an application by a father for an order allowing his children to visit him abroad when the children are resident and present in the province.

Also Phillips v. Stein, [ 1975] C.S. 3 I I and Jones v. Jones, [ 1975] C.S. 67 .

Jurisdiction - Divorce - Petitioner Employed by Government of Canada and on Staff of United Nations Posted Abroad in Different Countries but Maintaining Ottawa Address - Whether Domiciled in Canada, Ordinarily Resident in Ontario for One Year Immediately Preceding Petition and Actually Resident in Ontario for at Least Ten Months of that Period - Divorce Act, R.S.C. 197o, c. D-8 as am., s. 5(1) - Ontario Supreme Court

Doucet v. Doucet (1975), 4 O.R. (2d) 27. 
The court followed Wood v. Wood (Ig68), 2 D.L.R. (3d) 527 , 66 W.W.R. 702, 2 R.F.L. 48 and Marsellus v. Marsellus (I970), I 3 D.L.R. (3d), 383, 75 W.W.R. 746, 2 R.F.L. 53 and rejected Hardy v. Hardy, [1969] 2 O.R. 875, 7 D.L.R. (3d) 307, 2 R.F.L. $5^{\circ}$

Jurisdiction - Divorce - Residence - Divorce Act, R.S.C. 197o, c. D-8 as am., s. 5(I)(b) - Saskatchewan Queen's Bench

Zawatsky v. Zawatsky (1975), 2 I R.F.L. 370.

Where spouses are domiciled in Saskatchewan, and ordinarily resident there, a brief trial sojourn of slightly less than four months in another province within the year prior to the divorce hearing is not sufficient to deprive a Saskatchewan Court of jurisdiction under s. 5( I) (b) of the Divorce Act.

Jurisdiction - Foreign Company - Jurisdiction of Quebec Courts - Situs of Debt, Arts 68, 132, Code of Civil Procedure - Quebec Superior Court

West India Trading Company Inc. et autres c. Saguenay Shipping Ltd. et autres, [1975] R.P. 403 .

Service against a company executed as provided by the Code of Civil Procedure for service of a writ to a company is sufficient to give jurisdiction if that service is executed in the province.

The situs of a debt follows the person of the debtor not that of the creditor.

The fact that the debtor has accepted to pay his creditor outside his domicile does not deprive Quebec courts of jurisdiction.

Jurisdiction - Form of Submission to Jurisdiction - Supreme Court of Canada on Appeal from Quebec

Alimport (Empresa Cubana Importadora de Alimentos) v. Victoria Transport Ltd. (1976), 10 N.R. 451 .

In an action for breach of contract commenced in the Quebec courts by a certain purchaser of potatoes from a New Brunswick company, the Supreme Court of Canada held that no specific words of submission or election are required in order to determine whether the parties elected to submit to the Quebec courts. It is enough that the parties express their intention with sufficient clarity. 
Jurisdiction - Lis Pendens - Stay of Local Action - Principles to be Applied - Alberta Supreme Court, Appellate Division

Mohler v. Dairy Queen of Western Canada Ltd., [1976] 3 W.W.R. 6 ig.

Although the Supreme Court of Alberta had jurisdiction to hear the matter, the court should, when considering whether a stay should be granted, take into account the advantage to the plaintiff and the disadvantage to the defendant of continuing the action in Alberta. In the past, English courts had shown a reluctance to stay actions commenced in England where the plaintiff in the English action was a defendant in a foreign action. However, such a position appeared to have been abandoned in recent years to allow the courts to consider all the circumstances of the case in deciding whether its discretion should be exercised in granting a stay.

Jurisdiction - Marriage - Annulment - Quebec Code of Civil Procedure, Arts 68 and $70-$ Residence of Husband - Supreme Court of Canada

Doyle v. Doyle ( 1976), , о N.R. 250.

Compétence - Procédure - Lieu d'introduction de l'action Art. 68, Code procédure civile - Cour supérieure du Québec

Ferme Bergeron Inc. c. Société Coopérative Agricole de Laurierville, [ I975] C.S. 837 .

Jurisdiction - Service Ex Juris - Admiralty - Federal Court Arrest of Ship - Supreme Court of Canada

Antares Shipping Corp. v. The Ship "Capricorn" et al. (1976), 7 N.R. $5^{\text {I } 8,65}$ D.L.R. (3d) 105.

By Rule 307 of the Federal Court Rules, SOR/ 7 I-68, the court may permit service of a statement of claim out of the jurisdiction "in such place or country or within such limits as the Court thinks fit to direct." The appellant, a Liberian company, in pursuance of a claim against two other Liberian companies to ownership of a Liberian ship, arrested the ship in Canada and sought leave of the Federal Court to serve the defendants ex juris. The resolution of the dispute depended on contracts entered into outside Canada. The ship was released on the posting of a bond by one of the defendants. The trial 
court refused leave for service $e x$ juris on the ground that the dispute had no connection with Canada, and its decision was affirmed by the Federal Court of Appeal. On further appeal to the Supreme Court of Canada, the majority of the court allowed appeal. Leave to serve ex juris should be granted since it was not shown that any other jurisdiction was more appropriate than Canada for the determination of the dispute, and the bond posted in Canada offered the only practical means of enforcing any judgment that the plaintiff might obtain.

Laskin, C.J.C., dissented on the ground that the arrest of the ship in Canada was not a sufficient connection with Canada to justify the Court in assuming jurisdiction over the dispute.

Jurisdiction - Service Ex Juris - Absolute Right of Plaintiff under Ontario Rule 25 Superseding Former Discretion of Court - Ontario High Court

John Ewing \& Co. v. Pullmax (Can.) Ltd. (1976), I C.P.C. $25^{\text {I }}$.

The 1975 amendments to the Rules respecting service of process out of Ontario, in removing the need to obtain an order to authorize service $e x$ juris and in giving an absolute right to effect such service in all cases within the scope of amended Rule 25 , has eliminated the judicial discretion that existed under the former practice to withhold an order for service out of Ontario unless the case satisfied the spirit and the letter of the Rule, lest there be an unwarranted infringement on the sovereignty of foreign states. In consequence the plaintiff need not file an affidavit showing the existence of facts establishing a good arguable case on the merits in order to justify the service in any case coming within the wording of the rule. When there is no doubt as to propriety of service, there is no warrant for permitting a conditional appearance. It is submitted, however, that there is still room for invoking the doctrine of forum non conveniens.

Jurisdiction - Service Ex Juris - Breach of Contract to be Performed within Jurisdiction - Saskatchewan Court of Queen's Bench

Mid-North Hauling Ltd. v. Westbank Indust. Ltd., [1976] W.W.D. 32. 
Jurisdiction - Service Ex Juris - Proper and Necessary PartyOntario Rules 25(I)(j), 67-Ontario Court of Appeal

Jannock Corp. Ltd.v. R. T. Tamblyn \& Partners Ltd. et al. (1975), 8 O.R. (2d) 622.

Jurisdiction - Service Ex Juris - Meaning of "Damage Sustained in Ontario," Rule 25(I)(h) - Ontario High Court

Mar v. Block ( 1976 ), ı C.P.C. 206.

Damage means loss or harm caused by the opposite party. Medical expenses incurred in Ontario were simply part of the measure of the damage sustained in Saskatchewan.

Jurisdiction - Service Ex Juris - Contents of Ex Parte Application - British Columbia Supreme Court

Desbrisay v. Goldfield Corpn.; Can. Plywood Corpn. v. Goldfield Corpn., [1976] 5 W.W.R. $3^{02}$.

On an ex parte application under O. XI for an order for service outside the jurisdiction the applicant must produce sufficient evidence to satisfy the court the requirements of the rule have been met. The applicant must present facts which if proved disclose a cause of action that entitles the applicant to an order for such service as provided for under the rule.

Jurisdiction - Service Ex Juris - Insufficiency of Affidavit in Support of Application - New Brunswick Supreme Court

Nairn v. Archibald (1975), I3 N.B.R. (2d) 557.

Jurisdiction - Service Ex Juris - Forum Conveniens - Limitation of Actions - Nova Scotia Supreme Court, Trial Division

Benedict et al. v. Antuofermo (1975), 6o D.L.R. (3d) 469 .

The plaintiffs, residents of Nova Scotia, were injured in a motor vehicle accident in Ontario when their car was in collision with that of the defendant, a resident of the State of Illinois. The plaintiffs commenced proceedings in Nova Scotia and the defendant applied to set them aside on the ground that the Nova Scotia Court had no jurisdiction or should not take jurisdiction over the action. Alter- 
natively, the defendant sought to rely on the limitation period in the Ontario Highway Traffic Act, R.S.O. 1970, c. 202. The court dismissed the application on the ground that under rule ro of the Nova Scotia Rules of Court, an originating notice could be served without leave of the court in any Canadian province or American state. It could not be said that Nova Scotia was not the convenient forum or that the defendant would suffer any injustice or hardship. The Ontario limitation period, being procedural, had no application to proceedings in Nova Scotia.

Jurisdiction - Service Ex Juris - Forum Non Conveniens - Alberta Supreme Court

Mercantile Bank of Canada v. Hearsay Transport Ltd. et al. ( 1976 ), I Alta L.R. (2d) 238.

The principles applicable to staying an action on the ground that the courts of another jurisdiction are a more appropriate forum are similar to those applicable to an order to set aside an order for service ex juris.

Although R. 30 of the Alberta Rules of Court states that when any of the circumstances enumerated therein exist the court "may" allow service of the statement of claim outside of the jurisdiction, it does not require the court to grant an order whenever a case falls within one of those situations. What is required is the application of a disciplined discretion with necessary regard to whether the local forum is a proper one in light of all the circumstances attending the issues in dispute.

As to the defendants' motions in the instant case, the test in deciding whether such orders as are sought should be granted is not whether the domestic court is forum non conveniens but rather whether the plaintiff's choice of a forum is oppressive or vexatious or whether it constitutes an abuse of the process of the court in some way.

The court applied Antares Shipping Corpn. v. The "Capricorn" (1976), 65 D.L.R. (3d) 105, 7 N.R. $5^{18}$ (Can.); The "Atlantic Star" v. The "Bona Spes," [1974] A.C. 436, [1973] 2 All E.R. I 75; McKeeman v. C.P. Ltd. (1972), 33 D.L.R. (3d) 379 (Alta). 


\section{B. Procedure}

Contrat de vente - Interprétation - Loi étrangère - Application - Cour supérieure du Québec

Lafrenière Equipement Ltée c. Rondeau et autre, [1976] C.S. I9I.

Le tribunal ne peut pas prendre connaissance judiciaire d'office de la loi étrangère.

Cautionnement judicatum solvi-Défendeur étranger faisant requête en revision - Cour supérieure du Québec

W. et H. Management International c. International Bank et autres, [1975] R.P. 3 I2.

Le cautionnement judicatum solvi peut être exigé dans tous les cas de rétractation de jugement qui impliquent un débat distinct du bienfondé de l'action.

Testament - Cautionnement judicatum solvi-Succession ouverte au Québec - Exécuteur testamentaire domicilié hors du QuébecArt. 65, Code de procédure civile - Cour supérieure du Québec Arvanitakis c. Hellenic Canadian Trust, [1975] R.P. 391.

En ce qui concerne un demandeur ès-qualité, c'est l'endroit de la résidence de la personne représentée qui doit déterminer s'il y a lieu d'imposer un cautionnement judicatum solvi.

Un exécuteur testamentaire, domicilié en Grèce, n'est pas tenu audit cautionnement lorsque la succession s'est ouverte au Québec et que les biens qui la composent se trouvent situés dans la province.

Procédure - Cautionnement judicatum solvi-Cour supérieure du Québec, Lebrun c. Dompierre, [1976] R. P. 350

Un demandeur résidant hors du Québec est tenu de fournir un cautionnement même s'il possède des biens immobiliers dans la province. Cependant, dans le cas d'une demande par reconvention formulée contre lui la caution n'est pas requise. 
Extraprovincial Company - Unregistered - Not Carrying on Business in Province - Right to Commence Action to Restrain Defendant Company from Using the Plaintiff's Name-British Columbia Supreme Court

Browning-Ferris Industries, Inc. v. Browning-Ferris Industries, Inc., Remple et al., [1976] 3 W.W.R. 759.

Extra-Provincial Company Commencing Action - Date of Registration - Effect on Action - British Columbia Court of Appeal

Can. Stock Breeders Service Ltd. v. Reimer, [ 1976] 3 W.W.R. $44^{8}$ reversed on other grounds, [1976] 5 W.W.R. 405.

An unregistered extra-provincial company is not prevented under s. 335 (1) of the Companies Act, S.B.C. 1973, c. 1 8, from commencing an action in the province but may be prevented from continuing with the action until it is duly registered. Where plaintiff, an extraprovincial company, commenced an action at a time when it was not registered under the Act but did become registered one day before trial, the application by the defendant on the day of trial that plaintiff's action be dismissed because it was not registered when it commenced the action was denied.

Contra: see D-B Service (Western) Ltd. v. Madrid Services Ltd. (1975), 6o D.L.R. (3d) (B.C.S.C.), which must be considered as overruled.

Foreign Partnership - Right to Sue - British Columbia Court of Appeal

Skyline Associates v. Small, [1975] I W.W.R. $3^{85}$ affirmed $5^{6}$ D.L.R. (3d) 47 I.

Foreign Letters Rogatory - Ex Parte Order - Onus on Applicant Seeking to Enforce Order in Ontario to Establish Evidence Required for Trial not just for Discovery - Ontario County Court

Re Galamar Industries and Microsystems International Ltd. et al. (1975), io O.R. (2d) 22 I, 22 C.P.R. (2d) I9. 
Foreign Letters Rogatory-Application for Issue of Letters of Request to Various United States Courts to Permit Examination for Discovery - Jurisdiction - Absence of Reciprocity - Federal Court, Trial Division

Xerox of Canada Ltd. v. I.B.M. Can. Ltd., [1976] I F.C. 2 I3.

Proof of Foreign Law-Conflicting Expert Evidence - Responsibility of Court to Adopt its Own View of Foreign Law-Ontario High Court

Bausch Eீ Lomb Optical Co. v. Maislin Tpt Ltd. (1975), Io O.R. (2d) 533 .

Security for Costs - Plaintiff Residing in Ontario but Possessing Sufficient Assets within Jurisdiction - Reciprocal Legislation Providing that any Judgment for Costs Enforceable in Ontario - Application Dismissed - Nova Scotia Supreme Court, Trial Division

Djurasevic v. Can. Gen. Ins. Co. (1974), ${ }_{5}$ N.S.R. (2d) 37.

\section{Choice of Law}

Bankruptcy - Secured Creditors - Contract Made in QuebecLate Registration in Ontario - Ontario Supreme Court in Bankruptcy

Re Eye Patch Shop of Can. Ltd. (1975), 2 I C.B.R. (N.S.) 224.

An agreement of purchase and sale of certain goods was made in the province of Quebec, and the goods were delivered into the province of Ontario within 30 days from the date of bankruptcy of the purchaser. Subsequent to bankruptcy an order was made by a county court judge permitting late filing of the contract and the contract was then registered in the proper office. The court held that the vendor had rights under the Civil Code Art. I543 and a right to a revendication under Arts 1998 and 1999. These rights were enforceable in Ontario only if the vendor complied with the provisions of s. 12 of the Conditional Sales Act, R.S.O. 1970, c. 76. Pursuant to s. $2(7)$, the contract was effective only against creditors of, and subsequent purchasers or mortgagees claiming from, or under the purchaser in good faith and for valuable consideration from the date of registration. 
Chattel Mortgages - Registration - Removal to Other Province - Seizure - Alberta Supreme Court

Royal Bank of Canada v. College Mercury Sales Ltd., [1976] 3 W.W.R. I67.

For a chattel mortgage, granted, duly executed, and registered in the province of British Columbia, to be the basis for a seizure of the chattel subsequently removed to the Province of Alberta and sold, the chattel mortgage must be registered in Alberta according to the requirements of registration contained in the Bills of Sale Act of Alberta, R.S.A. 1970, c. 29. Thus a chattel mortgage, which by British Columbia legislation does not require an affidavit of bona fides of the grantee, must, when it is presented for registration in Alberta under s. I3, contain such an affidavit, as that is a requirement under s. 9; failure to provide such an affidavit results in the chattel mortgage not being properly registered in Alberta.

Chattel Mortgages - Registration - Sale to Bona Fide Purchaser - Priorities - Saskatchewan Court of Appeal

Re First National Bank and Schofield et al. (1975), 6o D.L.R. (3d) $75^{1}$.

By s. 13 of the Bills of Sale Act, R.S.S. 1 965 , c. 392, where chattels subject to a mortgage executed when they were outside the province are permanently removed into the province, the mortgage shall within 30 days be registered as a bill of sale, otherwise the mortgagee cannot set up his rights against a subsequent purchaser for value in good faith. A motor vehicle that was subject to a mortgage while in Nebraska was removed into Saskatchewan and sold to a good faith purchaser. Within 30 days of the removal of the vehicle into the province and after its sale to the purchaser the mortgagee seized it. In interpleader proceedings to determine the ownership of the vehicle the judge decided in favour of the mortgagee. On appeal by the purchaser, the court dismissing the appeal held that the mortgagee's rights, including the right of seizure, were preserved during the 3o-day period, and the mortgagee therefore took priority over the purchaser. The mortgagee's right of seizure did not depend on registration under the statute. 
Contract - Illegality - Gaming - Ontario High Court

Harold Meyers Travel Service Ltd. v. Magid (1975), 9 O.R. (2d) 200.

A promise in Ontario to repay money paid in respect of a legal gambling contract made abroad is enforceable.

Contrat - Loi applicable - Cour provinciale

Berlet Fruit Inc. c. Canadian Pacific Limited, [ 1975] R.P. 329.

Selon l'Article 8 du Code civil, en l'absence de choix exprès, un contrat s'interprète selon la loi du lieu où il a été passé.

Contract - Interpretation - Civil Code, Art. 8-Quebec Superior Court

Lusona Corpn. v. Sinyor Spinners of Can. Ltd. (I974), 22 G.P.R. (2d) 140.

The law of the state where the contract is made governs its interpretation and the obligations arising therefrom.

Contrat d'assurance vie - Loi applicable - C.c. 8. Cour d'Appel du Québec, Essiambre c. Mougeot et Autres, [1976] C.A. $65^{\circ}$

Le contrat doit s'interpréter selon la loi du lieu où il a été conclu. Le changement de bénéficiaires n'est qu'un incident du contrat initial et il est régi par la loi qui gouverne celui-ci.

Foreign Torts - Applicable Law - Newfoundland Supreme Court Comstock (Quebec) Ltd. v. United Assoc. of Journeymen and Apprentices of the Plumbing and Pipefiting Industry of the United States and Canada Local 740 (1975), 8 Nfld \& P.E.I.R. 199.

The court applied Phillips v. Eyre ( 1869 ), L.R. 6 Q.B. I.

Foreign Torts - Applicable Law - Proof of Foreign Law - Presumption of Identity - Extra-Provincial Company - Jurisdiction over - Alberta Supreme Court

Northern Alberta R. Co. v. K. E W. Trucking Co. Inc. (1975), 62 D.L.R. (3d) 378 . 
The court applied Phillips v. Eyre (1870), L.R. 6 Q.B. I. The court also was of the opinion that in proving the law of the place where the tort occurred, the plaintiff is entitled to rely on a presumption of law that the general law of that place is the same as the lex fori. The defendant corporation being registered and having a registered attorney in Alberta could be sued in that province, where it also carried on business.

Foreign Torts - Action on - Special Leave not Obtained - Nullity_-Saskatchewan Court of Queen's Bench

Kangles v. Canadian Pacific Hotels Ltd., [1976] 6 W.W.R. 94.

Lettre de change - Signée au Maroc et payable là-Parties domiciliées au Maroc - Tireur changeant de domicile - Prescription C.c. 219o-219I-Québec Cour provinciale

Betito c. Danino, [ 1976] G.P. I39

Marriage - Potentially Polygamous Marriage - Change of Domicile - Effect-Matrimonial Relief-Ontario High Court

Re Hassan and Hassan (1976), 12 O.R. (2d) 432.

A husband and wife who are parties to a potentially polygamous marriage concluded in their country of origin and who have migrated to Canada and taken up domicile in Ontario become subject to the law of Ontario and their marriage is thus converted de facto into a monogamous marriage. The parties to it are, therefore, entitled to matrimonial relief, including in the case of the wife, relief under the Deserted Wives' and Children's Maintenance Act, R.S.O. 1970, c. I28. The rule in Hyde v. Hyde et al. ( I886), L.R. I P. \& $D$. I 30 , denying such relief on the ground that the marriage is not a Christian one, does not apply in Canada, which invites immigrants from a wide variety of backgrounds and countries.

Mandat - Régime matrimonial - Preuve loi étrangère - Absence - Application de la loi du for au moment du mariage - Québec Cour provinciale

Varkony c. Suissa, [1976] C.P. I67. 
Régime matrimonial - Détermination - Domicile du mari en Ontario au moment du mariage-Mariage célébré au QuébecPremier domicile commun des époux au Québec - Régime matrimonial déterminé par le lieu du premier domicile commun-Code civil, arts 6, 7, 8, 175, 1260, 2202 - Cour supérieure du Québec

Martineau c. Martineau, [1975] C.S. I 137.

D. Foreign Judgments

Custody - Jurisdiction - Foreign Decree - Saskatchewan Queen's Bench

Cobel v. Cobel (1975), 2 I R.F.L. 343.

Newfoundland Court of Appeal

Re Hutchins ( 1976 ), 9 N. \& P.E.I.R. 438.

In divorce proceedings in Ontario the mother was given custody of the child. The child then went to live with an aunt and uncle in Newfoundland who later refused to give her back to the mother. The court held that the order made in Ontario was effective only between the parties to the divorce and did not affect the rights of third parties. Thus the court could exercise its inherent "parens patriae" jurisdiction to determine the welfare of the child.

Custody - Jurisdiction - Effect of Order Made Pursuant Divorce Act - Ontario Supreme Court

Renouf v. Renouf and Masters (1976), 23 R.F.L. 66.

An order made in another province pursuant to the ancillary provisions of the Divorce Act in respect of the custody and care of infants does not clog the powers of the Ontario courts under the Infants Act or the parens patriae doctrine where the infant is residing within Ontario at the time of the application.

Divorce - Custody - Variation - Saskatchewan Queen's Bench Papp v. Papp, [1976] 5 W.W.R. 673 . 
Custody-Effect of Interim Custody Order in Ontario Divorce Proceedings on Jurisdiction of British Columbia Court under the Equal Guardianship of Infants Act, R.S.B.C. 196o, c. 130-British Columbia Supreme Court

Re Bourque (1975), 20 R.F.L. 257.

Custody - Effect of Foreign Order - Prince Edward Island Supreme Court

Re Gallant (1975), 8 N. \& P.E.I.R. I I3.

Divorce - Custody - Order for Custody Obtained in British Columbia under Provincial Legislation - Wife Obtaining Interim Custody in Quebec Divorce Proceedings - Quebec Order Registered in British Columbia Renders the Original Order Ineffective - British Columbia Court of Appeal

Re Hall, [1976] 4 W.W.R. 634 .

Custody - Access - Effect Given to Ontario Order in British Columbia - British Columbia Supreme Court

Kibble v. Khan (1975), 20 R.F.L. 228.

Custody - Access - Divorce Granted in British Columbia Mother Moving with Children to Manitoba-Application to Vary Access Should be Made in Manitoba not in British ColumbiaBritish Columbia Supreme Court

Dakin v. Dakin (1975), 2 I R.F.L. 350.

Custody - Access - Geographical Limitation - New Brunswick Supreme Court

Re Murrin (1975), I2 N.B.R. (2d) 532; (1975), 23 R.F.L. $35^{6}$.

Divorce - Application in British Columbia to Vary and Rescind Maintenance Order Made in Divorce Trial in Ontario - Jurisdiction-British Columbia Court of Appeal

Rodness v. Rodness, [1976] 3 W.W.R. 414, 66 D.L.R. (3d) 746.

The only court with jurisdiction to vary or rescind a maintenance 
order made in a divorce trial is the court which made the order in the first instance. The British Columbia Court of Appeal overruled Hegg v. Hegg, [1973] 3 W.W.R. 307, 12 R.F.L. 385, 36 D.L.R. (3d) 29 I and Blashill v. Blashill, [1974] 2 W.W.R. 397, I4 R.F.L. I96, 43 D.L.R. (3d) 637 .

For a similar view see the decision of the Ontario Court of Appeal in Ramsay v. Ramsay and Innes (1976), 23 R.F.L. 147. See also obiter dictum to the effect that s. I I (2) of the Divorce Act, R.S.C. I 970 , c. D-8 as am., does not eliminate the parens patriae power of the superior courts over infants within their territorial jurisdiction where an order for custody has been made under that Act by a court of another province unless such power has been removed or limited by express legislation. Ramsay v. Ramsay and Innes was applied in Blane v. Blane (1976), 23 R.F.L. I95 (Ont. C.A.).

Divorce prononcé au Nouveau Brunswick - Pension alimentaire Requête en modification - Défaut de jurisdiction-Objection rejetée - Cour d'appel du Québec

Stern c. Phillips, [1976] C.A. I5o.

Divorce - Recognition of Foreign Decree - Grounds - Supreme Court of Canada

Powell v. Cockburn (1976), 68 D.L.R. (3d) 700, 8 N.R. 2 I5.

Fraud going to the jurisdiction of the foreign court is a good ground for refusing to recognize the foreign decree of divorce. The court did not expressly decide whether it should recognize foreign decrees granted by a jurisdiction with which the petitioner or respondent had a real and substantial connection. See Indyka v. Indyka, [1969] i A.C. 33 (H.L.).

Divorce - Recognition of Foreign Decree-Divorce Act, R.S.C. 197o, c. D-8, s. 6(2) - British Columbia Supreme Court

La Carte v. La Carte (1975), 6o D.L.R. (3d) 507, 23 R.F.L. I 12.

Where a foreign court grants a decree of divorce to a wife who resides and is domiciled within the jurisdiction of that court, there are two bases upon which the decree could be recognized in Canada: s. 6 (2) of the Divorce Act and the principle of Indyka v. Indyka, [r969] I A.C. 33; [1967] 2 All E.R. 689. The court held that she 
had had a real and substantial connection with Florida when the decree was granted and that the divorce could be recognized on the basis of Indyka.

Divorce - Recognition of Foreign Divorce - Manitoba Court of Appeal

Holub v. Holub, [1976] 5 W.W.R. 527.

The court, applying Indyka v. Indyka, [ I969] I A.C. 33, [ 1967] 2 All E.R. 689 (H.L.), recognized a German decree of divorce since, at the relevant time, the husband had a real and substantial connection with Germany.

Foreign Judgment for Maintenance-Special Endorsement not Possible - Ontario High Court

Small v. Zacher (1975), 8 O.R. (2d) 372.

Foreign Judgment-Recognition-Allegiance not a Sufficient Basis for Jurisdiction of Foreign Court - Ontario County Court

Patterson v. D'Agostino ( 1975), 8 O.R. (2d) 367.

Foreign Judgment - Recognition and Enforcement - Jurisdiction of Foreign Court - Ontario County Court

First National Bank of Oregon v. Harris (1975), ro O.R. (2d) $5^{16}$.

Where a defendant has unsuccessfully disputed a foreign court's jurisdiction over him and has thereby attorned to the foreign court, he cannot raise the same issue of jurisdiction in an action to enforce the judgment in Ontario.

Foreign Judgments - Reciprocal Enforcement - Jurisdiction of Foreign Court - Voluntary Appearance - Defences - Recriprocal Enforcement of Judgments Act R.S.N.B. 1973, c. R-3, s. 5; Foreign Judgments Act, R.S.N.B. 1973, c. F-19, s. 5 (b) -New Brunswick Supreme Court, Queen's Bench Division

MacFarlane v. Briggs (1976), I 5 N.B.R. (2d) I 53.

The court held that to provide authority for the making of an $e x$ parte registration order of a foreign judgment the personal service of 
the writ of summons in the original action must have been made within the jurisdiction of the original court. The court was also of the opinion that the debtor would have had a defence if an action were brought on the original judgment.

Maintenance Order - Confirmation - Jurisdiction - Reciprocal Enforcement of Maintenance Orders Act, 1968 (Sask.), c. 59, s. 7 - Saskatchewan District Court

Skakun v. Skakun, [1976] 6 W.W.R. 283.

Pension alimentaire - Loi d'exécution réciproque d'ordinances alimentaires, S.R.O. 1964, c. 23 -Arrérages ne s'arréragent pasCour supérieure du Québec

Read Robertson c. Read et autres, [1975] C.S. 845 . 